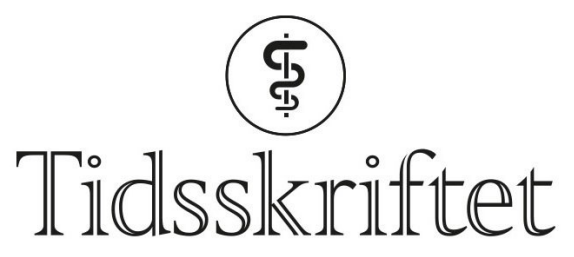

DEN NORSKE LEGEFORENING

\title{
Mindre omfattende kirurgi ved brystkreft like bra
}

FRA ANDRE TIDSSKRIFTER

PETTER MORTEN PETTERSEN

Tidsskriftet

Det er unødvendig å gjøre full aksilledisseksjon hos brystkreftpasienter med metastaser i 1-2 vaktpostlymfeknuter. Dette viser ny studie.

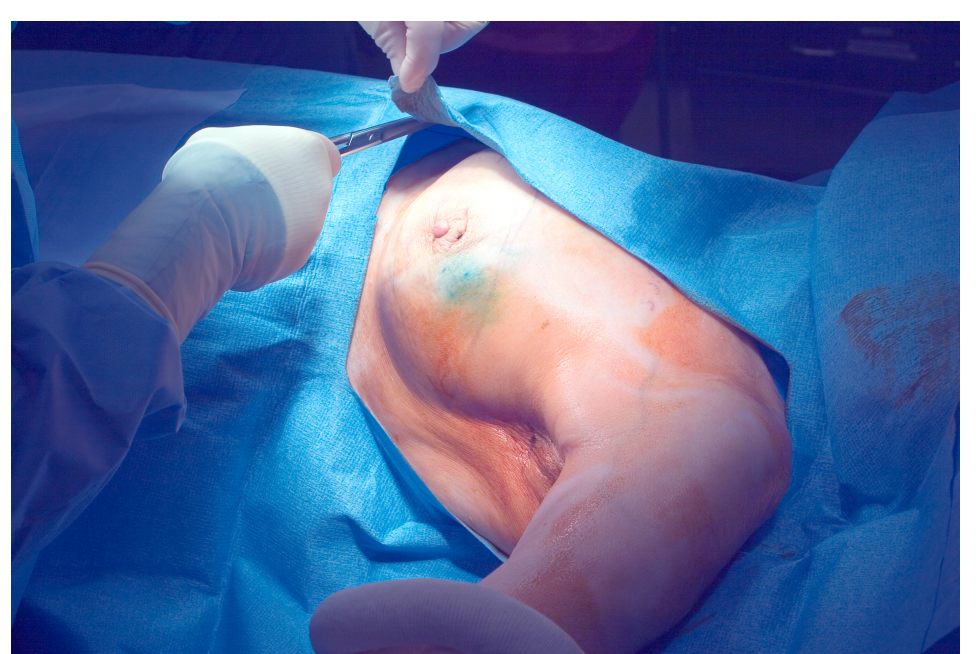

Forberedelse til vaktpostlymfeknutebiopsi og modifisert radikal mastektomi. Foto: Science Photo Library

Tidligere omfattet kirurgisk behandling av brystkreft fjerning av alle lymfeknuter i armhulen, såkalt aksilledisseksjon, dersom det under utredningen ble funnet spredning til vaktpostlymfeknuter. I de senere år har man gått bort fra denne praksisen.

I en ny amerikansk studie ble 856 kvinner med brystkreft med primærtumor på under $5 \mathrm{~cm}$ (T1 eller T2) og metastaser til én eller to vaktpostlymfeknuter randomisert til enten fjerning av vaktpostlymfeknutene eller til full aksilledisseksjon (1). Ingen av pasientene hadde palpable lymfeknuter i armhulen. Alle fikk tilleggsbehandling med stråling og cellegift.

Etter ti år var overlevelsen om lag den samme hos dem som fikk fjernet vaktpostlymfeknuter som hos dem som fikk aksilledisseksjon (86,3\% og 83,6\%). Sykdomsfri overlevelse var henholdsvis $80,2 \%$ og $78,2 \%$.

- Denne studien bekrefter funn ved tidligere studier, men med betydelig lengre observasjonstid, sier Ellen Schlichting, som er seksjonsleder ved Seksjon for bryst- og endokrinkirurgi ved Oslo universitetssykehus. - Norge var et av de første landene i Europa 
der man sluttet å fjerne alle lymfekjertler i armhulen selv om det var metastaser til én eller to vaktpostlymfeknuter, forteller hun. - Det er nå bare ca. $10 \%$ av dem med brystkreft som trenger aksilledisseksjon. Tusenvis av brystkreftpasienter blir dermed spart for et unødvendig stort aksilleinngrep og senkomplikasjoner som lymfødem og smerteproblematikk, sier Schlichting.

\section{LITTERATUR:}

1. Giuliano AE, Ballman KV, McCall L et al. Effect of axillary dissection vs no axillary dissection on 10year overall survival among women with invasive breast cancer and sentinel node metastasis. JAMA 2017; 318: 918 - 26. [PubMed][CrossRef]

Publisert: 12. desember 2017. Tidsskr Nor Legeforen. DOI:10.4045/tidsskr.17.0844

(C) Tidsskrift for Den norske legeforening 2020. Lastet ned fra tidsskriftet.no 